\title{
KAJIAN STRUKTUR BANGUNAN TRADISIONAL JAWA PADA BANGSAL KENCANA KERATON YOGYAKARTA
}

\section{Padmana Grady Prabasmara \\ Fakultas Teknik Jurusan Arsitektur Universitas Widya Mataram Yogyakarta padmana.grady@gmail.com}

\section{Satrio HB Wibowo}

Fakultas Teknik Jurusan Arsitektur Universitas Widya Mataram Yogyakarta satriohb@ymail.com

\section{Tri Yuniastuti}

Fakultas Teknik Jurusan Arsitektur Universitas Widya Mataram Yogyakarta triyuni3@gmail.com

\begin{abstract}
ABSTRAK
Keraton Yogyakarta yang kini lebih dikenal sebagai destinasi wisata adalah museum hidup yang menunjukkan fungsi sebagai tempat tinggal Raja, pusat pemerintahan kerajaan dan sebagai pusat kebudayaan yang terdiri dari bangunan-bangunan bergaya tradisional Jawa yang sangat penting artinya. Sebagai bangunan cagar budaya yang dilindungi undang-undang dan sebagai warisan budaya bangsa, bangunan Keraton Yogyakarta memiliki karakteristik dan keistimewaan, antara lain usianya yang sudah lama, kerumitan konstruksi dan keindahan ornamennya. Berlatar belakang hal itulah penelitian ini dilakukan untuk mengetahui karakteristik bangunan keraton dan dilakukan sesuai dengan adat dan tatalaku yang terjadi di keraton Yogyakarta. Kajian terhadap Struktur Bangunan Tradisional Jawa yang terdapat di komplek Keraton Yogyakarta, khususnya bangunan bangsal Kencana perlu dilakukan dengan cara mendata keberadaan bangunan Tradisional Jawa, mengenali bentuk bangunan, sejarah, fungsi dan struktur bangunan serta kelengkapan komponennya. Kajian dilakukan dari hasil observasi, studi literatur, wawancara dan kajian hasil penelitian terdahulu. Hasil yang didapatkan adalah dokumen tertulis tentang aspek sejarah, fungsi dan struktur bangunan disertai gambar-gambar bentuk bangunan dan gambar-gambar detail yang menunjukkan keunikan struktur bangunan. Kajian ini diharapkan dapat menjadi pengetahuan dan pedoman pelestarian bangunan Tradisional Jawa serta menjadi inspirasi pengembangan budaya pada masa depan yang bersumber dari budaya lokal, dan menjadi pendorong generasi muda untuk tetap mencintai budaya sendiri dengan mengembangkan citra Arsitektur Nusantara.
\end{abstract}

KATA KUNCI: struktur, tradisional jawa, bangsal, fungsi, Keraton Yogyakarta

\section{PENDAHULUAN}

Keraton Kasultanan Yogyakarta yang berada di pusat kota Yogyakarta, Provinsi Daerah Istimewa Yogyakarta, berdiri pada tahun 1755 sebagai hasil dari perjanjian Giyanti pada tanggal 13 Februari 1755 antara Pangeran Mangkubumi; adik Sunan Pakubuwono II, raja Keraton Surakarta, dengan pihak Kolonial Belanda. Menurut Balai Pelestarian Peninggalan Purbakala Yogyakarta, 2003 dan dari berbagai sumber diketahui bahwa puncak dari wujud visual arsitektur keraton Yogyakarta terjadi di masa pemerintahan Sri Sultan Hamengkubuwono VIII (1921-1939) seperti yang dapat kita lihat sekarang ini. Sebelumnya bangunan keraton terbangun secara bertahap yang dilakukan oleh raja-raja yang berkuasa pada jamannya mulai dari bangsal Prabayaksa dan Siti Hinggil Lor tahun 1769; bangsal Pagelaran dengan tratag bambu di tahun 1896; penggunaan marmer dari Italia untuk bangsal Kencana di masa Sri Sultan Hamengkubuwono VI dan bangsal Manis serta kompleks Siliran di masa Sri Sultan Hamengkubuwono VII. Di dalam Keraton Yogyakarta, arsitektur
Tradisional Jawa merupakan gaya arsitektur yang pokok atau utama. Hal tersebut dapat dilihat dengan banyaknya bangunan-bangunan yang bergaya Tradisional Jawa di dalam komplek keraton, sebagaimana juga dikemukakan dalam Kratons of Java (1991) bahwa bangunan-bangunan paling penting di keraton menggunakan atap joglo yang terbentuk dari bentuk-bentuk piramid dan trapesium. Demikian juga dikemukakan oleh Eko Punto Hendro G., dalam Tri Yuniastuti dan Satrio HB Wibowo (2007) bahwa ditinjau dari atapnya, bangunan-bangunan di keraton menggunakan atap pelana, limasan, tajug dan joglo.

Salah satu bentuk bangunan di lingkungan Keraton Yogyakarta yang menjadi kekhasan arsitektur Tradisional Jawa adalah bangunan bangsal. Bangunan tersebut bersifat terbuka (pendapa). Dari hasil pengamatan selama ini tercatat setidaknya terdapat 20 bangunan berbentuk bangsal di dalam keraton yang berciri khaskan bangunan rumah tradisional Jawa asli, seperti bangsal Kencana, bangsal Sri Manganti, bangsal Ponconiti, bangsal Manguntur Tangkil, bangsal Witono, bangsal Magangan, bangsal 
Kesatriyan, bangsal Trajumas, bangsal Kemandungan, dalem Ksatriyan, dalem Prabayaksa, Kraton Kilen dan bangunan lainnya dengan masingmasing fungsi yang berbeda.

Secara khusus bangunan-bangunan bangsal bergaya Tradisional Jawa digunakan sebagai tempat dengan fungsi-fungsi utama atau penting dalam keraton. Karakteristik bangunan-bangunan bangsal di keraton dengan gaya Tradisional Jawa dengan berbagai kelengkapannya menjadi hal yang unik, langka dan bernilai sejarah yang tinggi. Keunikan dan kelangkaannya mengingat bahwa hanya di Keraton Yogyakarta saja bangunan-bangunan itu berada dan lestari. Bahkan pengembangan tipologi joglo dengan klasifikasi tertinggi yaitu joglo lambang gantung yang dikembangkan oleh Sri Sultan Hamengkubuwono I juga hanya terdapat di Keraton Yogyakarta. Selain itu juga bernilai sejarah mengingat bahwa bangunanbangunan bergaya Tradisional Jawa di keraton dibangun oleh raja-raja Jawa sejak ratusan tahun silam yang mewakili kebesaran dan keindahan pada zamannya. Kini bangunan-bangunan tersebut menjadi warisan cagar budaya yang tak ternilai harganya dikarenakan merupakan akar budaya Jawa dan bangsa Indonesia pada umumnya dan akar arsitektur Indonesia pada khususnya.

\section{TIPOLOGI ARSITEKTUR TRADISIONAL JAWA JOGLO}

Tipologi Joglo memiliki 8 (delapan) varian yaitu Joglo Pokok, Limasan Lawakan, Sinom, Jompongan, Pangrawit, Mangkurat, Hageng dan Semar Tinandu. Masing-masing tipologi tersebut, setidaknya harus memiliki ciri-ciri atap terdiri 4 buah soko guru dengan pe-midangannya (ulengnya) dan memiliki blandar tumpang sari, sebuah bubungan di tengahnya. Rumah bentuk joglo merupakan bentuk rumah tradisional Jawa yang paling sempurna yang hanya dimiliki oleh kalangan orang-orang mampu atau orang-orang terpandang. Secara substansif, joglo didesain untuk pendapa yang letaknya di bagian depan dan bukan difungsikan untuk tempat tinggal dikarenakan dalam paham Jawa bangunan di depan tidak layak untuk tempat tinggal yang bersifat privat. Hal-hal lain yang mendukung kelayakan fungsi joglo sebagai pendapa adalah ruangnya yang luas sehingga ideal digunakan untuk kegiatan pertemuanpertemuan. Beberapa tipologi bangunan tradisional Jawa Joglo dapat dilihat pada gambar 1.

Konstruksi bangunan adalah suatu hubungan antar komponen-komponen bangunan meliputi pondasi lantai, dinding, tiang, balok, langit-langit, dan atap, dengan hubungan saling ketergantungan dengan tujuan menunjang kegunaan atau fungsi, kekuatan, keawetan, dan keamanan (Ronald, 1997: 449).

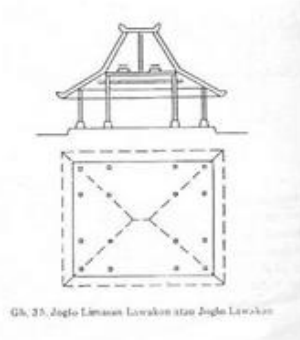

Joglo Lawakan

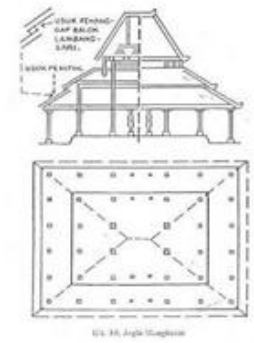

Joglo Lambang Gantung
Gambar 1. Tipologi bangunan Joglo

(Sumber : HJ Wibowo, dkk., 1986/1987)

Sistem struktur pada bangunan joglo sangat erat hubungannya dengan konstruksi antar komponen karena secara keseluruhan saling mendukung dan saling berkaitan. Pekerjaan konstruksi dimulai dari komponen paling bawah bangunan, yakni pondasi, kemudian makin ke atas sampai komponen teratas. Perkembangan bentuk joglo berakibat juga berkembangnya sistem struktur dan konstruksinya (lihat gambar 2). Bentuk bangunannya semakin unik, semakin besar, semakin luas, membawa konsekuensi pada struktur dan konstruksi yang juga menjadi lebih unik dan rumit (Ronald, 1997: 281).
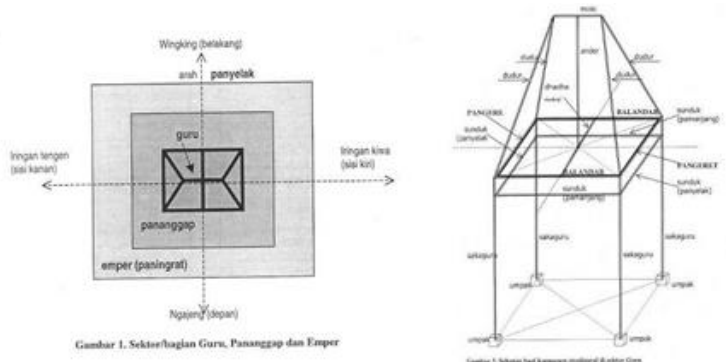

Gambar 2. Pembagian sektor atap dan komponen rangka Soko Guru (Sumber : Prijotomo., 2005 )

Secara fisik arsitektural bangunan-bangunan di kawasan keraton menggunakan langgam tradisional Jawa dengan kekhasan berupa bentuk bangunan pendapa, atap joglo, tajug, limasan dan kampung. Dari karakteristiknya, bangunan-bangunan di keraton terdiri dari bangunan terbuka tanpa dinding penutup dan bangunan tertutup yang dilengkapi dengan dinding (gambar 3). Bangunan terbuka di keraton disebut bangsal dan bangunan tertutup disebut sebagai gedhong (KPH. Brongtodiningrat, 1978).

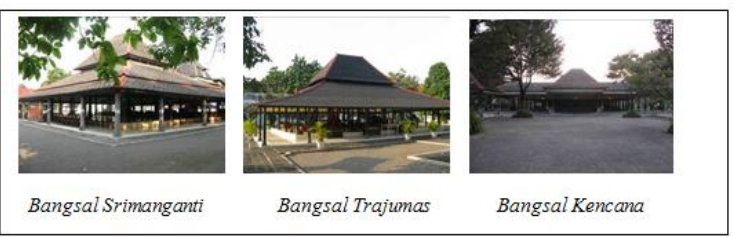

Gambar 3. Bangsal Kencana di Keraton Yogyakarta (Sumber : Pengamatan, 2010-2011) 
Jenis bangunan lainnya yang terdapat di keraton adalah bangunan yang telah terkena pengaruh arsitektur Eropa. Pengaruh budaya Eropa terhadap bangunan-bangunan di Keraton Yogyakarta mengakibatkan munculnya unsur-unsur arsitektur Klasik Eropa ke dalam komplek keraton dengan munculnya bangunan-bangunan baru bergaya Klasik Eropa, terutama pada bangunan Gedhong dan Regol (Tri Yuniastuti dan Satrio HBW, 2007), sebagaimana dapat dilihat pada gambar 4 .

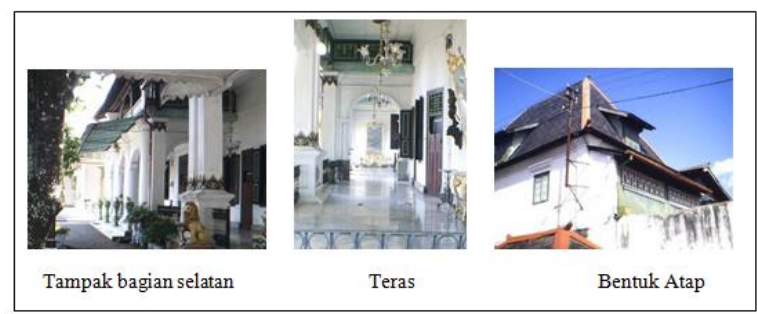

Gambar 4. Gedhong Purworetno bergaya Arsitektur Eropa (Sumber : Tri Yuniastuti dan Satrio HBW, 2007)

\section{METODE PENELITIAN}

Lokasi obyek penelitian terletak di dalam komplek Keraton Kasultanan Yogyakarta. Secara administratif termasuk dalam kecamatan Kraton, Kotamadya Yogyakarta, Daerah Istimewa Yogyakarta. Secara visual, letak dan gambaran kondisi visual bangunan bangsal keraton Yogyakarta yang akan diteliti pada tahap III ini dapat dilihat pada gambar 5 .

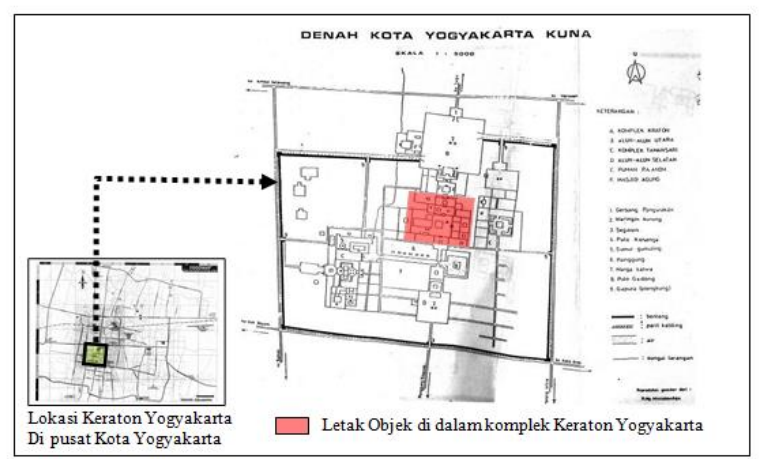

Gambar 5 . Lokasi Keraton Yogyakarta dan objek penelitian

(Sumber : data diolah)

Objek penelitian pada tahap ketiga ini adalah bangunan bangsal bergaya arsitektur Tradisional Jawa di dalam komplek Keraton Yogyakarta yang terletak di bagian dalam keraton yang terlarang bagi masyarakat umum atau wisatawan untuk memasukinya. Untuk memasuki dan melakukan penelitian dengan pengamatan, pemotretan dan pengukuran terhadap bangunan dan komponenkomponennya, peneliti telah mendapatkan izin khusus dari pihak yang berwenang, yaitu Tepas Wahono Sarto Kriyo Keraton Yogyakarta. Bangsalbangsal yang menjadi objek penelitian tahap III ini adalah Bangsal Probayeks, Bangsal Kencana dan Bangsal Manis.

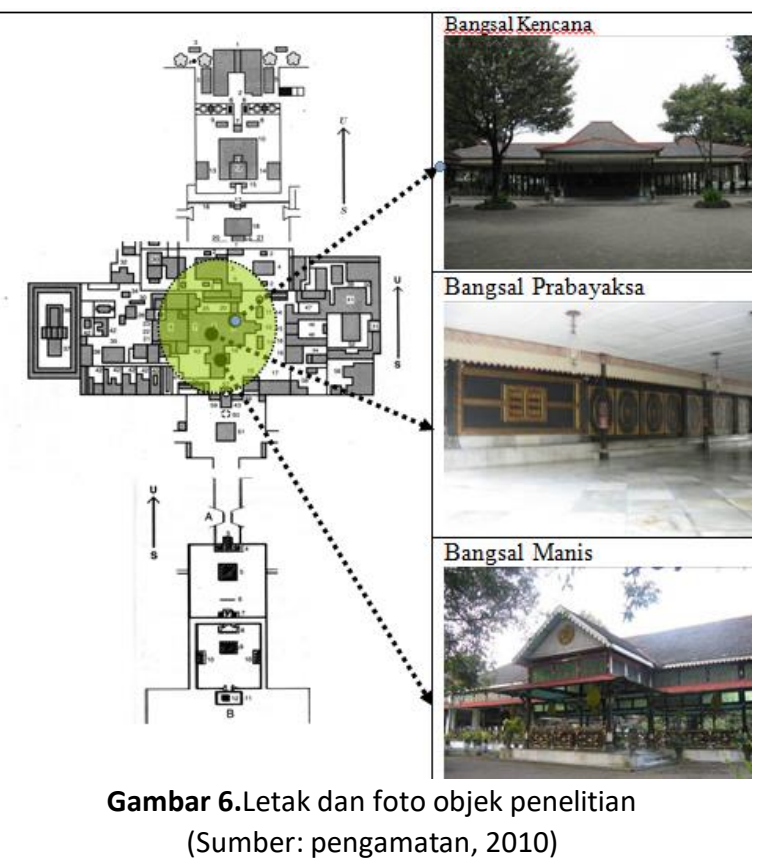

Pengambilan setiap komponen pada setiap bangunan yang diteliti dilakukan dengan menginventaris jenis atau macam kerangka yang sama bentuk, ukuran dan fungsinya. Jika setiap jenis berjumlah lebih dari satu, maka diambil salah satu saja untuk diteliti. Sebagai contoh lihat gambar 7 .

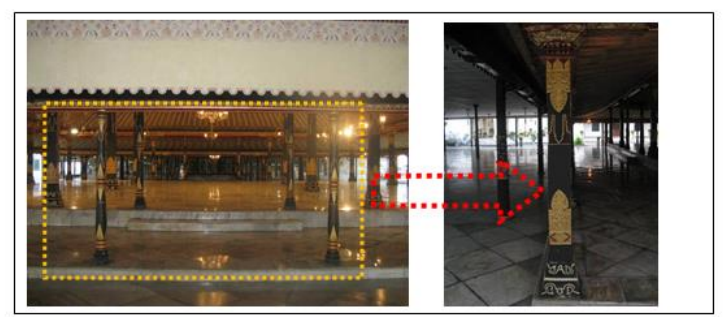

Gambar 7. Contoh pengambilan sampel komponen bangunan pada Bangsal Kencana (Sumber : data diolah)

Metode pengumpulan data dilakukan dengan survey langsung untuk mendapatkan data primer dan survey tidak langsung. Survey langsung untuk mendapatkan data primer dilakukan dengan cara pengamatan atau observasi di lapangan terhadap objek penelitian untuk mendapatkan data secara akurat dengan cara pendokumentasian melalui pengukuran, pengkopian atau penjiplakan obyek, pemotretan maupun pencatatan. Juga dilakukan wawancara dengan pihak yang memiliki data terkait objek penelitian. Kegiatan survey dapat dilihat dalam gambar 8 . 


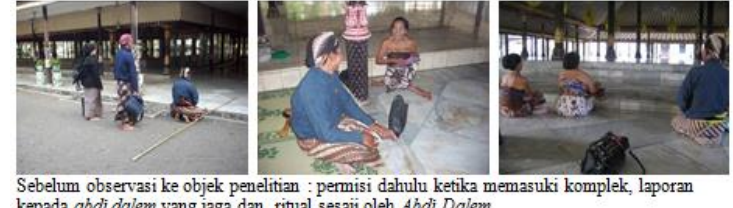
kepada abdi dalem yang jaga dan ritual sesaji oleh Abdi Dalem.
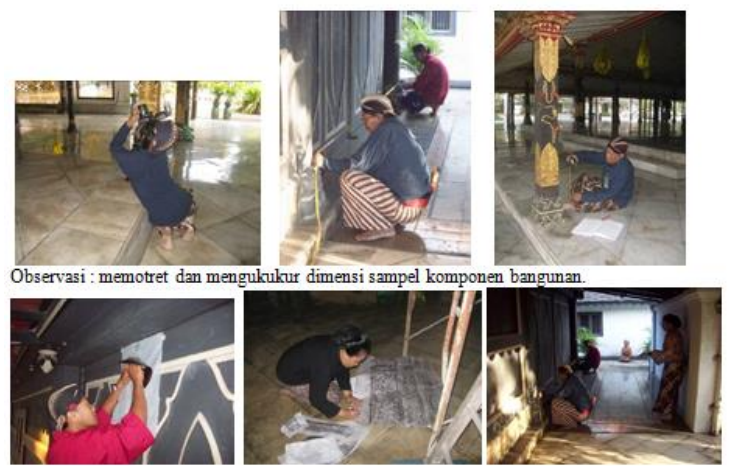

Gambar 8. Kegiatan survey langsung (Sumber: pengamatan, 2011)

Observasi yang dilakukan meliputi pengamatan fisik bangunan, pencatatan ukuran bangunan, panjang dan lebar ruang, tinggi ruang, dimensi kerangka, posisi dan jarak rangka bangunan, dan sebagainya. Pengukuran dilakukan pada keseluruhan bangunan beserta bagian-bagiannya untuk mendapatkan dimensi bangunan secara akurat. Pengambilan data ukuran menggunakan alat bantu, 1) meteran dengan ukuran 50 meter dan 5 meter; 2) penggaris logam $30 \mathrm{~cm}$ dan $100 \mathrm{~cm}$; 3) penggaris sikusiku; 4) kertas dan alat tulis; 5) tangga aluminium 2 bh; 6) tampar (tali) besar; dan 7) galah panjang dan pendek.

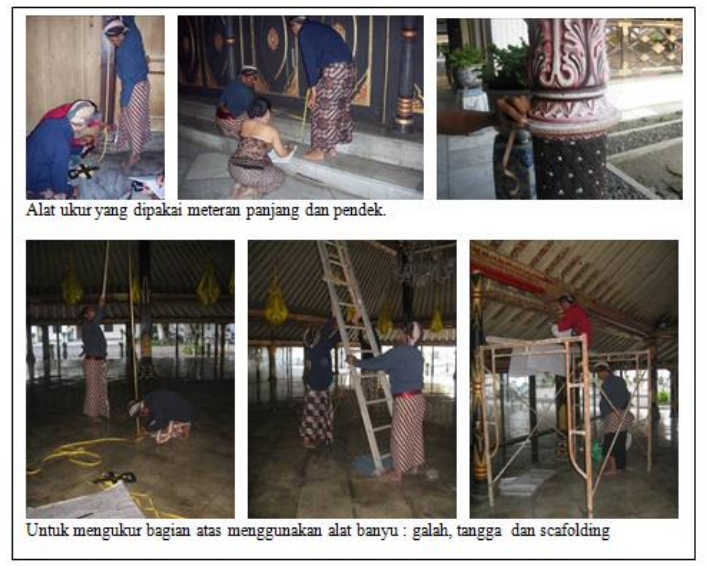

Gambar 9. Kegiatan pengukuran

(Sumber: dokumentasi kegiatan, 2011)

Data pengamatan yang didapatkan dari lapangan digambar ulang ke dalam komputer dengan program Auto CAD maupun Corel Draw. Selain itu teknik pemotretan juga dilakukan untuk mendapatkan data visual bagian-bagian bangunan yang diteliti. Hasil pemotretan diolah ke dalam komputer dengan program Adobe Photoshop.
Survey tidak langsung untuk mendapatkan data sekunder dilakukan dengan merekam data melalui 1) studi pustaka; 2) survey instansional; dan 3) wawancara. Survey ini bertujuan untuk mendapatkan data pendukung keberadaan objek. Data yang dicari berupa karakteristik fisik bangunan meliputi bentuk bangunan maupun bagian-bagian bangunan, sejarah bangunan, filosofi bangunan, fungsi bangunan, ornamen dan filosofinya, tata ruang bangunan, hingga bentuk-bentuk pelestarian bangunan cagar budaya pada bangunan.

Kegiatan studi pustaka dilakukan untuk memperoleh data terkait objek penelitian dari dokumen penelitian yang telah dilakukan. Wawancara ditujukan kepada pihak-pihak yang terkait dengan keberadaan bangunan di Keraton Yogyakarta, yaitu Pengageng Tepas Wahono Sarto Kriyo Keraton Yogyakarta sebagai pengelola bangunan keraton, pemandu wisata, para abdi dalem, dan pemerhati bangunan bersejarah di Yogyakarta. Wawancara dilakukan secara langsung dengan narasumber, dicatat dan direkam dengan alat rekam digital. Wawancara dimaksudkan untuk memperoleh data fungsi bangunan, perlakuan khusus terhadap bangunan, bentuk pelestarian yang pernah dilakukan, riwayat bangunan, bentuk-bentuk perlindungan terhadap bangunan bersejarah, filosofi bangunan, filosofi ragam hias, kedudukan serta upacara-upacara ritual di dalam bangunan dan filosofinya.

Analisis dilakukan dalam tiga tahap yaitu analisis informasi, proses penafsiran dan penyimpulan hasil. Proses analisis informasi dilakukan dengan 1) memaparkan secara keseluruhan karakteristik arsitektur bangunan dan bagian-bagian obyek penelitian secara kuantitatif dan kualitatif; 2) melakukan interpretasi terhadap informasi data yang ada. Interpretasi dilakukan terhadap bentuk bangunan, proporsi, ragam hias, dan aspek-aspek karakteristik, ciri khas, estetika, filosofi dan sebagainya.

Proses penafsiran dilakukan melalui 1) penyelidikan atau kajian terhadap hasil intepretasi data; 2) penyelidikan atau kajian terhadap nilai-nilai ukuran bangunan, struktur dan konstruksi, dan ornamen; 3) penyelidikan atau kajian terhadap nilainilai arsitektural dari sisi fungsi, estetika, gaya bangunan, struktur konstruksi, kesejarahan, keunikan dan kelangkaan maupun keselamatan bangunan. Keseluruhan proses penafsiran dilakukan dengan dukungan teknik korelasi dan komparasi sehingga diperoleh hasil analisis yang akurat. Korelasi dilakukan dengan menghubungkan berbagai sudut pandang, misalnya tentang kebesaran kerajaan dengan nilai bangunan, fungsi bangunan dengan pemakaian jenis ragam hias, usia bangunan dengan kondisi bahan bangunan, struktur dan konstruksi 
dengan dampak gempa dan sebagainya. Komparasi dilakukan terhadap beberapa bangunan lain yang sejenis untuk mendapatkan nilai karasteristik objek yang diteliti.

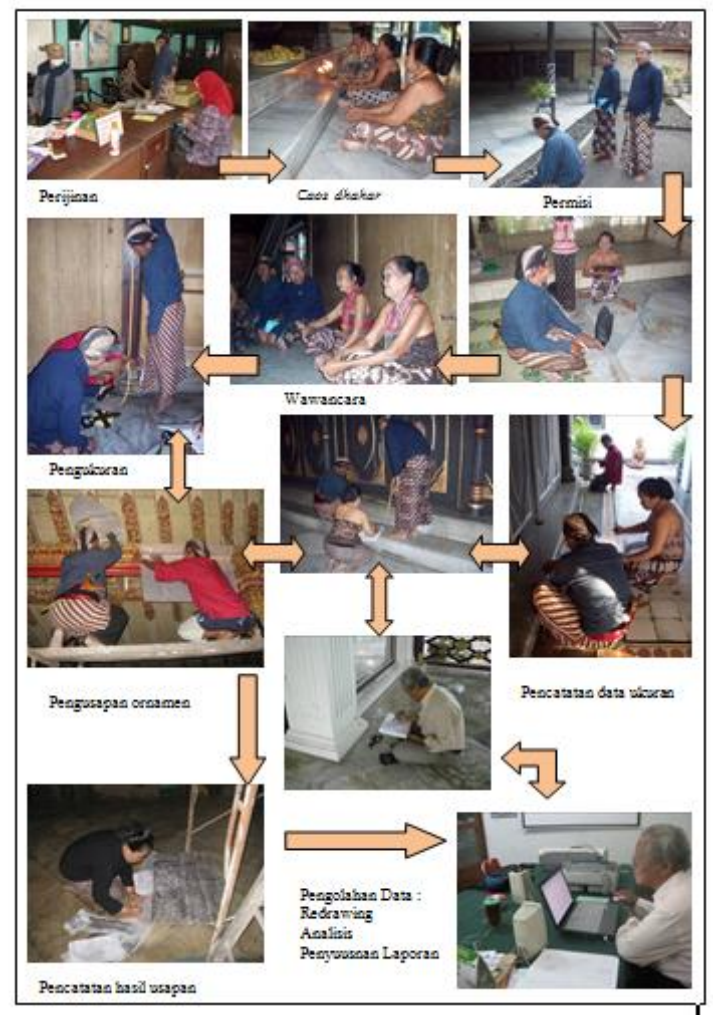

Gambar 10. Proses penelitian

(Sumber: dokumentasi kegiatan, 2011)

\section{HASIL PENELITIAN}

\section{Tipologi bangunan}

Kajian tipologi bangunan Bangsal Kencana di halaman Kedhaton dilihat dari sisi jenis atap terdiri atas dua tipologi Joglo Lambang Gantung. Bangsal Kencana merupakan bangunan joglo yang terbesar, terindah, termegah, di antara joglo-joglo yang ada di dalam komplek Keraton Yogyakarta. Bangunan di dalam Keraton yang semakin tinggi status fungsinya, maka bangunan itu dibuat semakin indah.

Atap Bangsal Kencana bersusun tiga, terdiri dari atap yang posisinya paling atas adalah atap utama yaitu atap brunjung, di bawahnya adalah atap penanggap, dan yang paling bawah dan terakhir adalah atap penitih. Bangunan Bangsal Kencana ini merupakan bangunan rumah tradisional Jawa yang tergolong dalam kelompok joglo lambang gantung karena atap penaggapnya menggantung pada atap brunjung. Sambungan atap penanggap terhadap atap penitihnya merupakan bentuk sambungan atau susunan atap lambang sari. Kolom atau tiangnya juga terdiri dari tiga macam, yaitu dimulai dari tiang utama yang menyangga atap brunjung disebut saka guru, tiang yang menyangga atap penanggap disebut sakapenanggap, dan tiang yang menyangga atap penitih disebut saka penitih.

Balok lainnya yang posisinya diagonal adalah dudur dan usuk atap penanggap dan dudur dan usuk atap penitih. Dudur kedua atap dihias penuh dengan motif lung-lungan, sedang masing-masing usuk kedua atap itu dihias lung-lungan pada sisi bawah bagian ujung atas dan sisi bawah ujung bawah.

Seluruh sisi tiang dan balok rangka yang tampak, dihias dengan motif-motif, dicat dengan bahan perada emas dan warna dasar relief merah. Warna dasar rangka bangunan Bangsal Kencana dicat warna gelap, yakni hitam kecoklatan, sehingga seluruh ornamennya tampak kontras terhadap warna dasar rangka bangunannya. Jumlah susunan balok-balok rangka di daerah pemidhangan atau area di antara blandar-pengeretbrunjung sangat banyak dan padat, begitu juga ornamen-ornamennya, sehingga menghasilkan efek memfokuskan penglihatan di antara seluruh ruang bangunan Bangsal Kencana. Fokus penglihatan, atau dapat disebut dengan istilah center of interest, digiring oleh hiasan-hiasan yang berada di luar area pemidhangan, dimulai dari area penitih terus ke area penanggap, dan menuju area paling tengah yaitu pemidhangan.

Bentuk dasar saka guru, saka penanggap dan saka penitih adalah balok empat persegi panjang, sehingga memiliki empat buah sisi tegak dengan masing-masing sisi untuk semua jenis saka tersebut dihiasi motif-motif ornamen yang sejenis. Tata letak ornamen dan macamnya yang terdapat pada setiap saka guru, saka penanggap dan saka penitih adalah sama. Perbedaannya adalah pada ukuran setiap jenis motif pada setiap jenis tiang yang sangat tergantung pada perbedaan panjang pendeknya ukuran setiap jenis tiang atau saka. Perbedaan ukuran tiang atau saka mengakibatkan perbedaan ukuran motif-motif hiasan pada setiap jenis saka. Ukuran motif hias pada saka guru lebih besar dan lebih panjang atau lebih tinggi bila dibanding dengan ukuran motif-motif yang ada pada saka penanggap, begitu pula bila dibandingkan dengan ukuran motif-motif pada saka penitih. Saka totol berbentuk dasar silender, berfungsi untuk membantu menyangga blandar penitih, oleh karena itu masing-masing saka totol didirikan di antara dua buah saka penitih. 


\begin{tabular}{|c|c|c|c|c|c|}
\hline $\begin{array}{l}\text { Kompo } \\
\text { nen }\end{array}$ & \multicolumn{5}{|c|}{ Sektor Bangunan } \\
\hline $\begin{array}{l}\text { Keselu- } \\
\text { ruhan }\end{array}$ & 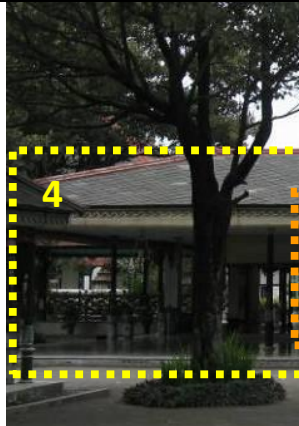 & 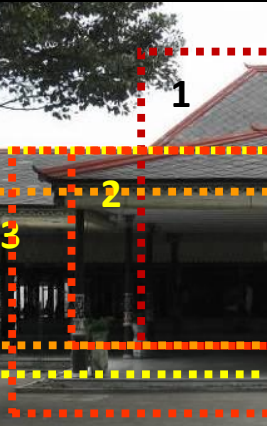 & Hine & (A)Ig & $\begin{array}{ll}\text { 1. } & \begin{array}{l}\text { Bagian } \\
\text { brunjung }\end{array} \\
\text { 2. } & \begin{array}{l}\text { Bagian } \\
\text { Penanggap }\end{array} \\
\text { 3. } & \begin{array}{l}\text { Bagian } \\
\text { Penitih }\end{array} \\
\text { 4. } & \begin{array}{l}\text { Bagian Tratag } \\
\text { dan Emper }\end{array} \\
\text { 5. } & \text { Bagian } \\
\text { kuncung }\end{array}$ \\
\hline & Brunjung & Penanggap & Penitih & Tratag & Emper \\
\hline Atap & $\begin{array}{l}\text { Atap Brunjung } \\
\text { berbentuk prisma segi } \\
\text { empat, terletak di } \\
\text { tengah bangunan } \\
\text { sebagai puncak atap. }\end{array}$ & $\begin{array}{l}\text { Atap Penanggap } \\
\text { menggantung pada } \\
\text { saka bentung } \\
\text { disetiap sudut }\end{array}$ & $\begin{array}{l}\text { Atap Penitih } \\
\text { mengelilingi atap } \\
\text { Penanggap, }\end{array}$ & $\begin{array}{l}\text { Atap Tratag } \\
\text { berbentuk } \\
\text { Limasan. Terletak } \\
\text { di sisi Timur dan } \\
\text { Barat } \\
\text { Lebih tinggi dari } \\
\text { atap penitih }\end{array}$ & $\begin{array}{l}\text { Atap Emper terletak } \\
\text { di sisi utara dan } \\
\text { selatan bangsal } \\
\text { Lebih tinggi dari atap } \\
\text { penitih }\end{array}$ \\
\hline Usuk & $\begin{array}{l}\text { Usuk Brunjung } \\
\text { tertutup Balok Uleng } \\
\text { dan langit-langit } \\
\text { pemidangan }\end{array}$ & $\begin{array}{l}\text { Usuk Penanggap } \\
\text { disusun seperti } \\
\text { rangka payung } \\
\text { menumpang di } \\
\text { antara balok } \\
\text { gantung dan balok } \\
\text { penanggap. }\end{array}$ & $\begin{array}{l}\text { Usuk Penitih } \\
\text { disusun seperti } \\
\text { rangka payung } \\
\text { menumpang di } \\
\text { antara balok } \\
\text { penanggap dan } \\
\text { balok penitih. }\end{array}$ & $\begin{array}{l}\text { Usuk Tratag tidak } \\
\text { kelihatan, } \\
\text { tertutup plafon } \\
\text { yang dipasang }\end{array}$ & $\begin{array}{l}\text { Usuk Emper tidak } \\
\text { kelihatan, tertutup } \\
\text { plafon yang dipasang }\end{array}$ \\
\hline Sektor & Brunjung & Penanggap & Penitih & Tratag & Emper \\
\hline Balok & $\begin{array}{l}\text { 1.Dada Peksi } \\
\text { 2. Balok Uleng } \\
\text { 3. Balok Blandar } \\
\text { 4. Balok Sunduk/Kili }\end{array}$ & $\begin{array}{l}\text { Balok Gantung } \\
\text { Balok Blandar } \\
\text { Penanggap }\end{array}$ & 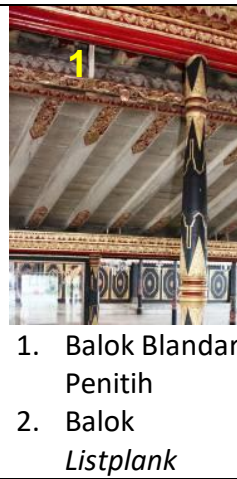 & $\begin{array}{l}\text { 1. Penutup } \\
\text { plafon } \\
\text { 2. Tiang besi } \\
\text { 3. Penutup } \\
\text { talang }\end{array}$ & $\begin{array}{l}\text { 1. Penutup talang } \\
\text { 2. Tiang besi } \\
\text { 3. Penutup plafon }\end{array}$ \\
\hline $\begin{array}{l}\text { Tiang / } \\
\text { Kolom/ } \\
\text { Saka }\end{array}$ & & & & & \\
\hline
\end{tabular}




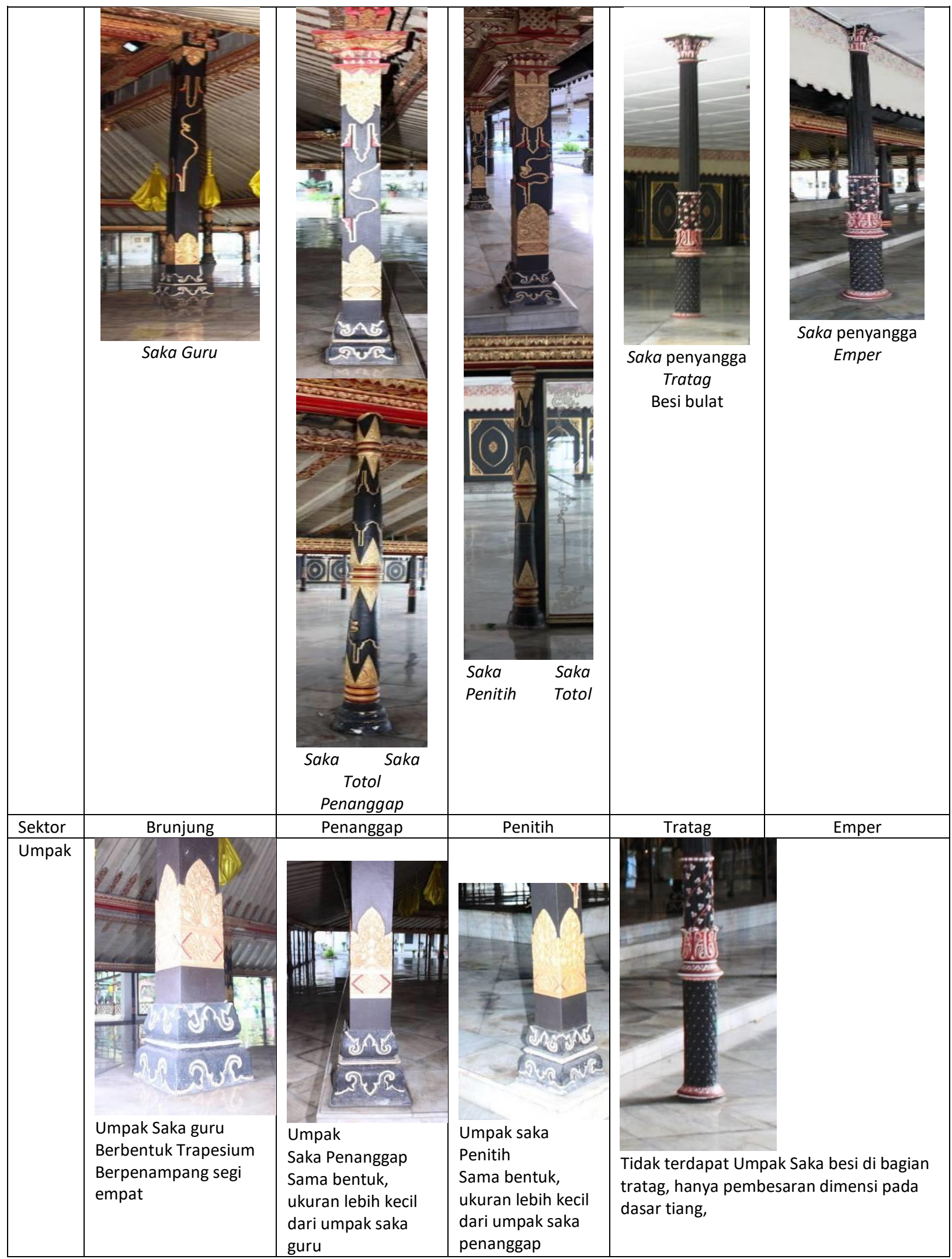




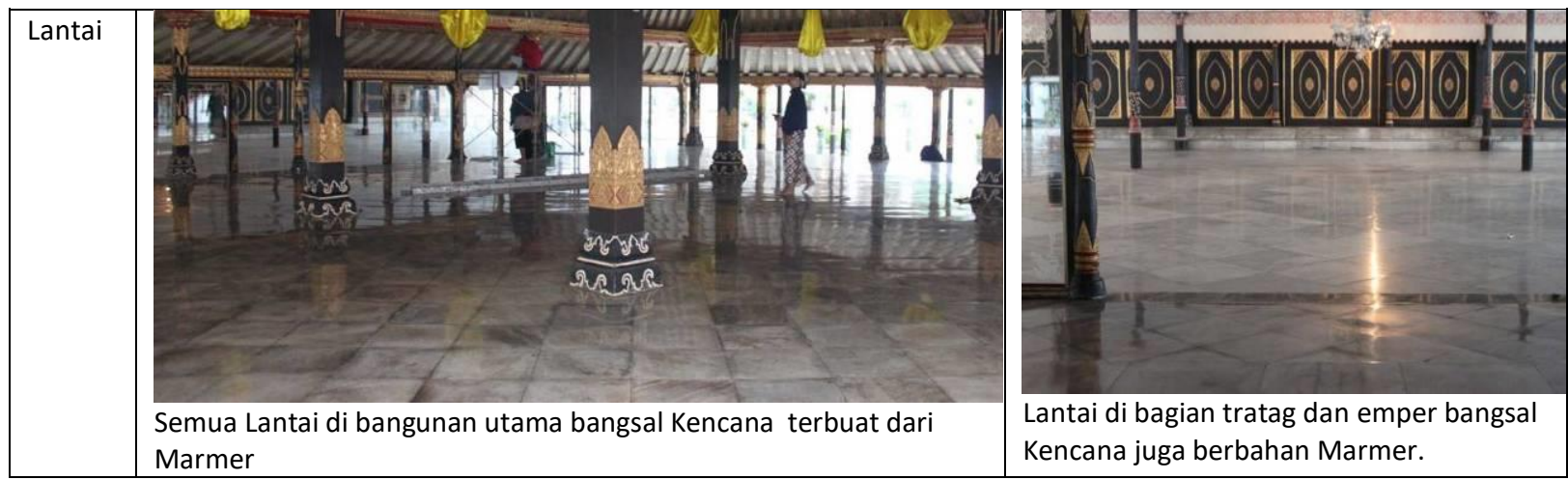

\section{KESIMPULAN}

Kajian ini bertujuan untuk mengidentifikasi bangunan di Keraton Yogyakarta, khususnya Bangsal Kencana yang masih asli. Dari kajian ini didapatkan kesimpulan bahwa :

1. Bangunan Bangsal Kencana di Keraton Yogyakarta memiliki ciri yang sama, yaitu terbuka dan merupakan bangunan tradirional Jawa dengan tipologi Joglo Lambang Gantung.

2. Tipologi tersebut merupakan yang tertinggi tingkatannya, hal ini disesuaikan dengan fungsi atau penggunaannya untuk kegiatan utama keraton yang melibatkan Sultan.

3. Bangsal Kencana sebagai bangunan dengan fungsi kerajaan paling utama, kemegahan ditunjukkan selain dengan ukuran bangunan dan kerumitan strukturnya, juga dengan ornamen yang banyak dan lengkap dengan finishing yang megah dan menampilkan lambang-lambang kekuasaan.

\section{DAFTAR PUSTAKA}

1991, Kratons of Java, Indonesia:
Departemen Telekomunikasi.

Brongtodiningrat, K. (1978). Arti Kraton Yogyakarta. Museum Kraton Yogyakarta.

G., Eko Punto. (2001). Kraton Yogyakarta dalam Balutan Hindu. Semarang: Bendera Semarang.

Prijotomo, J. (1995). Petungan: Sistem Ukuran Dalam Arsitektur Jawa. Yogyakarta: Gadjah Mada University Press.

Ronald, A. (1997). Ciri-ciri Karya Budaya Di Balik Tabir Keagungan Rumah Jawa. Yogyakarta: Universitas Atmajaya Yogyakarta.

Sukirman. (2011). Ragam Hias Bangsal Witana Sitihinggil Utara Keraton Yogyakarta, Kajian Iconologis. Tesis PascaSarjana Institut Seni Indonesia (ISI) Yogyakarta.
Tri Yuniastuti dan Satrio HB Wibowo . (2007). Pengaruh Arsitektur Klasik Eropa Pada Bangunan Kraton Kasultanan Yogyakarta. Laporan Hasil Penelitian.

Tri Yuniastuti, Sukirman dan Satrio HB. (2009). Dokumentasi Bangunan Bangsal Tradisional Kraton Yogyakarta. Laporan Hasil Penelitian Penelitian.

Tri Yuniastuti, Sukirman dan Satrio HB. (2010). Dokumentasi Bangunan Bangsal Tradisional Kraton Yogyakarta. Laporan Hasil Penelitian Penelitian.

Wibowo, H. (1986/1987). Rumah Tradisional Daerah Istimewa Yogyakarta. Dedikbud. 